\title{
A rare cause of dysphagia
}

\author{
Yan-Lin Li, Max Kai-Ho Yam, Jeremy Man-Leung Yu
}

Department of Radiology, Queen Mary Hospital, University of Hong Kong, Pokfulam, Hong Kong

\section{Correspondence to Dr Yan-Lin Li, jyl.li@mensa. org.hk}

Accepted 3 June 2017
CrossMark

To cite: Li Y-L, Yam MK-H, Yu JM-L. BMJ Case Rep Published Online First: [please include Day Month Year]. doi:10.1136/bcr-2017220773

\section{DESCRIPTION}

A middle-aged woman presented with dysphagia and globus sensation. Upper endoscopy was unremarkable and barium swallow revealed persistent, smooth indentation of the posterior aspect of the upper thoracic oesophagus at T4 level, suggesting external compression (figure 1). Subsequent CT thorax demonstrated an aberrant right subclavian artery compressing the posterior oesophagus (figure 2). A diagnosis of dysphagia lusoria was made.

The aberrant right subclavian artery is present in $0.5 \%-2 \%$ of the population. Normally, the right subclavian artery arises from the brachiocephalic trunk and becomes the axillary artery after passing the right first rib. The aberrant right subclavian artery arises from the aortic arch distal to the origin of the left subclavian artery, travelling behind the oesophagus before continuing its original course. This malformation is thought to arise from abnormal involution of the embryonic fourth right aortic arch. It is usually sporadic but association with trisomy 21 and congenital heart disease has also been reported.

Most patients are asymptomatic. A minority develop dysphagia typically of adult onset. Upper endoscopy is typically normal but sometimes a pulsatile bulge can be seen. Barium swallow classically shows an indentation over the posterior aspect of the oesophagus at T4 level on lateral view, in addition to normal impressions from the aortic arch, left main bronchus and left atrium. The diagnosis can be confirmed with cross-sectional imaging. ${ }^{2}$

Surgery to reconnect the aberrant right subclavian artery to the right common carotid artery is an effective treatment for patients with severe symptoms. ${ }^{1}$

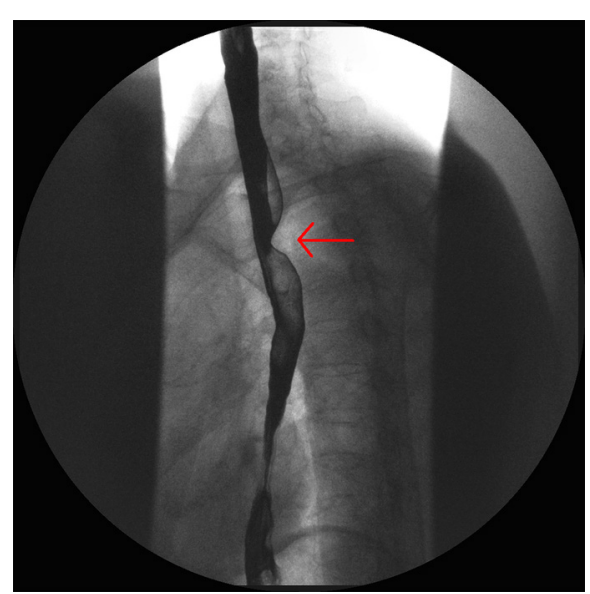

Figure 1 Coned lateral view of the barium swallow showed an indentation over the posterior wall of the upper thoracic oesophagus at T4 vertebral level.

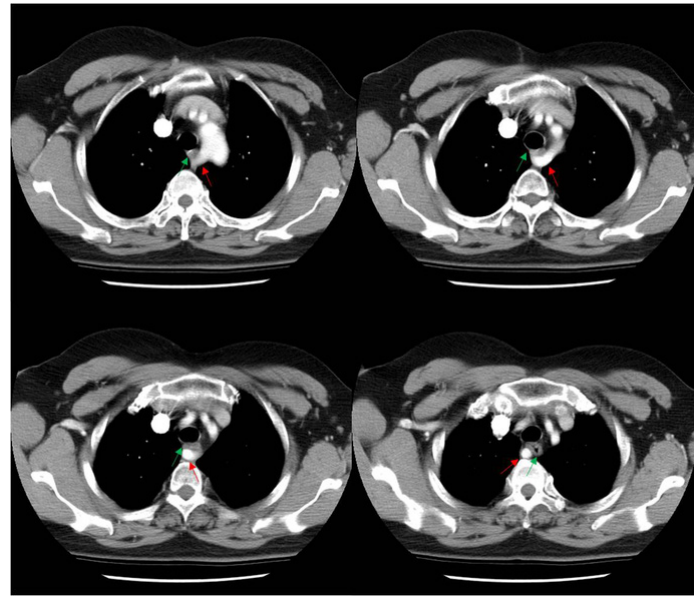

Figure 2 Contrast-enhanced CT of the thorax showed an aberrant origin of the right subclavian artery from the aortic arch distal to the left subclavian origin (red arrow), with compression to the posterior aspect of the oesophagus (green arrow).

Learning points

- The aberrant right subclavian artery is a congenital malformation that is commonly asymptomatic but can also cause dysphagia by compression to the posterior oesophagus.

- Clinicians and radiologists should be aware and suspect the condition during routine investigations for dysphagia (endoscopy and barium swallow) to facilitate diagnosis with cross-sectional imaging.

- Despite being a congenital malformation, most patients present in adulthood and a high degree of clinical suspicion is required.

Contributors YLL conceived of the study and prepared the manuscript. MKHY and JMLY assisted in preparing the manuscript. Competing interests None declared.

Patient consent Detail has been removed from this case description/these case descriptions to ensure anonymity. The editors and reviewers have seen the detailed information available and are satisfied that the information backs up the case the authors are making.

Provenance and peer review Not commissioned; externally peer reviewed

(C) BMJ Publishing Group Ltd (unless otherwise stated in the text of the article) . All rights reserved. No commercial use is permitted unless otherwise expressly granted.

\section{REFERENCES}

1 Carrizo GJ, Marjani MA. Dysphagia lusoria caused by an aberrant right subclavian artery. Tex Heart Inst J 2004;31:168-71. 


\section{Images in...}

2 Janssen M, Baggen MG, Veen HF, et al. Dysphagia lusoria: clinical aspects, manometric

Copyright 2017 BMJ Publishing Group. All rights reserved. For permission to reuse any of this content visit http://group.bmj.com/group/rights-licensing/permissions.

BMJ Case Report Fellows may re-use this article for personal use and teaching without any further permission.

Become a Fellow of BMJ Case Reports today and you can:

- Submit as many cases as you like

Enjoy fast sympathetic peer review and rapid publication of accepted articles

- Access all the published articles

- Re-use any of the published material for personal use and teaching without further permission

For information on Institutional Fellowships contact consortiasales@bmjgroup.com

Visit casereports.bmj.com for more articles like this and to become a Fellow 